October 2001 - NREL/CP-520-31023

\title{
A Combinatorial Approach to TCO Synthesis and Characterization
}

\section{Preprint}

J. Perkins, J. Alleman, J. del Cueto, X. Li,

T. Coutts, D. Young, P. Parilla, B. Keyes,

L. Gedvilas, D. Balzar, Q. Wang, and D. Ginley

National Renewable Energy Laboratory

D. Readey and C. Duncan

Colorado School of Mines

R. Stauber

University of Colorado, Boulder

To be presented at the NCPV Program Review Meeting Lakewood, Colorado

14-17 October 2001

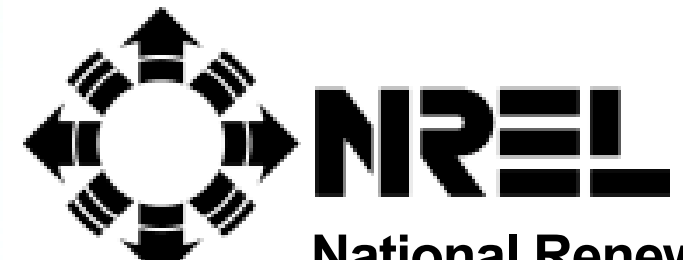

National Renewable Energy Laboratory

1617 Cole Boulevard

Golden, Colorado 80401-3393

NREL is a U.S. Department of Energy Laboratory

Operated by Midwest Research Institute $\bullet$ Battelle $\bullet$ Bechtel

Contract No. DE-AC36-99-G010337 


\section{NOTICE}

The submitted manuscript has been offered by an employee of the Midwest Research Institute (MRI), a contractor of the US Government under Contract No. DE-AC36-99G010337. Accordingly, the US Government and MRI retain a nonexclusive royalty-free license to publish or reproduce the published form of this contribution, or allow others to do so, for US Government purposes.

This report was prepared as an account of work sponsored by an agency of the United States government. Neither the United States government nor any agency thereof, nor any of their employees, makes any warranty, express or implied, or assumes any legal liability or responsibility for the accuracy, completeness, or usefulness of any information, apparatus, product, or process disclosed, or represents that its use would not infringe privately owned rights. Reference herein to any specific commercial product, process, or service by trade name, trademark, manufacturer, or otherwise does not necessarily constitute or imply its endorsement, recommendation, or favoring by the United States government or any agency thereof. The views and opinions of authors expressed herein do not necessarily state or reflect those of the United States government or any agency thereof.

Available electronically at http://www.osti.gov/bridge

Available for a processing fee to U.S. Department of Energy and its contractors, in paper, from:

U.S. Department of Energy

Office of Scientific and Technical Information

P.O. Box 62

Oak Ridge, TN 37831-0062

phone: 865.576 .8401

fax: 865.576.5728

email: reports@adonis.osti.gov

Available for sale to the public, in paper, from:

U.S. Department of Commerce

National Technical Information Service

5285 Port Royal Road

Springfield, VA 22161

phone: 800.553 .6847

fax: 703.605.6900

email: orders@ntis.fedworld.gov

online ordering: http://www.ntis.gov/ordering.htm

Printed on paper containing at least $50 \%$ wastepaper, including $20 \%$ postconsumer waste 


\title{
A Combinatorial Approach to TCO Synthesis and Characterization
}

\author{
J. Perkins, D. Readey, ${ }^{2}$ J. Alleman, J. del Cueto, X. Li, T. Coutts, R. Stauber, ${ }^{1}$ C. Duncan, ${ }^{2}$ D. Young, P. Parilla, \\ B. Keyes, L. Gedvilas, D. Balzar, ${ }^{3}$ Q. Wang, and D. Ginley \\ National Renewable Energy Laboratory, Golden, CO, 80401, U.S.A. \\ ${ }^{1}$ University of Colorado, Boulder, CO, 80309, U.S.A. \\ ${ }^{2}$ Colorado School of Mines, Golden, CO, 80401, U.S.A. \\ ${ }^{3}$ National Institute of Standards and Technology, Boulder, CO 80303, U.S.A.
}

\begin{abstract}
New and optimized metal-oxide thin films for both transparent-conductor and antireflection coatings have the potential to significantly improve photovoltaic devices. One approach to this task of discovery and improvement is to use a parallel optimization, i.e., a combinatorial, approach. Using internal seed funds, we have developed the initial deposition, characterization and analysis tools necessary for implementing a combinatorial approach to thin-film metal oxides, with a special focus on transparent conducting oxides (TCOs).
\end{abstract}

\section{Introduction}

Transparent conducting oxides [1] play a key role in a number of thin-film opto-electronic devices, including photovoltaics, flat panel displays, low-e windows, electrochromic devices, and anti-static coatings [2]. The bulk of these applications rely on the established n-type transparent conducting oxides (TCOs), such as $\mathrm{SnO}_{2}: \mathrm{F}$, $\mathrm{ZnO}: \mathrm{Al}$, and indium-tin-oxide (ITO) [3]. For many of these technologies, next-generation devices would be significantly enhanced with improved or new TCOs [4]. This is leading to the investigation of new n-type materials such as $\mathrm{Cd}_{2} \mathrm{SnO}_{4}, \mathrm{Zn}_{2} \mathrm{In}_{2} \mathrm{O}_{5}$, and $\mathrm{In}_{2-2 \mathrm{x}} \mathrm{Sn}_{\mathrm{x}} \mathrm{Zn}_{\mathrm{x}} \mathrm{O}_{3}$. These more complex materials are generally alloys of the simpler established transparent conducting metal oxides such as $\mathrm{CdO}, \mathrm{SnO}_{2}, \mathrm{ZnO}, \mathrm{In}_{2} \mathrm{O}_{3}$, and $\mathrm{Ga}_{2} \mathrm{O}_{3}$. Combinatorial

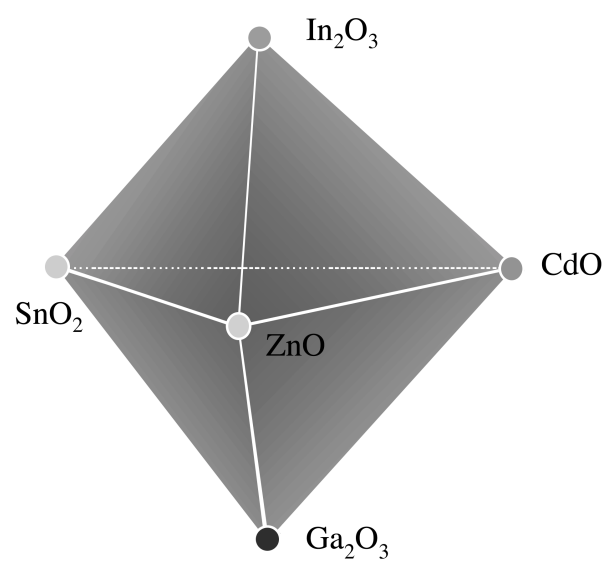

Fig. 1. Pictorial representation of the potential phase space of current interest for new TCOs [1].

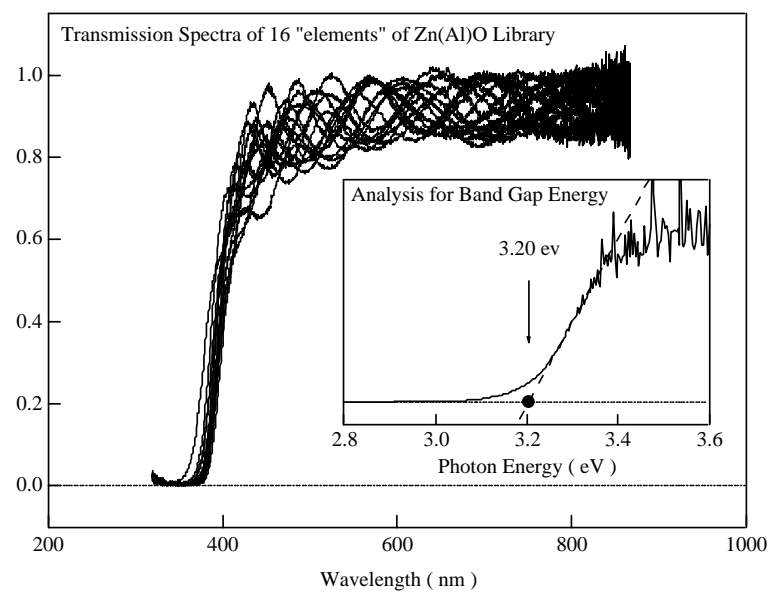

Fig. 2. Optical transmission spectra of 16 elements of a sputtered $\mathrm{Zn}(\mathrm{Al}) \mathrm{O}$ library.

approaches are thus needed to explore realistically the large compositional space represented by Figure 1 [5]. Combinatorial approaches are composed of three components: library deposition, critical-parameter analysis, and data mining to extract useful information and conclusions.

\section{Combinatorial Deposition and Characterization}

$\mathrm{Zn}(\mathrm{Al}) \mathrm{O}$ and $\mathrm{Zn}-\mathrm{Sn}-\mathrm{O}$ libraries have been deposited by co-sputtering using a three-gun sputtering system specifically built for combinatorial deposition. Cd-Sn-O libraries have been grown by chemical vapor deposition on an existing system by utilizing system-generated compositional gradients.

Figure 2 shows the optical transmission spectrum for 16 elements of a $\mathrm{Zn}(\mathrm{Al}) \mathrm{O}$ library. These spectra are measured using a UV/VIS/NIR CCD-based fiber-optically coupled spectrometer with measurement times of $\sim 1 \mathrm{sec}$. per full spectrum. Figure 3 shows the infrared reflectivity vs. photon energy for an 18-element $\mathrm{Cd}-\mathrm{Sn}-\mathrm{O}$ library grown by CVD. All elements show the increasing infrared reflectivity due to the free-electron plasma oscillations indicative of a conductor. In the inset, the reflectance at $3000 \mathrm{~cm}^{-1}$ (circles, left axis) and the Hall-measured carrier concentration (triangles, right axis) are both plotted vs. the sample number. The good correlation shows that the infrared reflectivity is a viable noncontact diagnostic for 


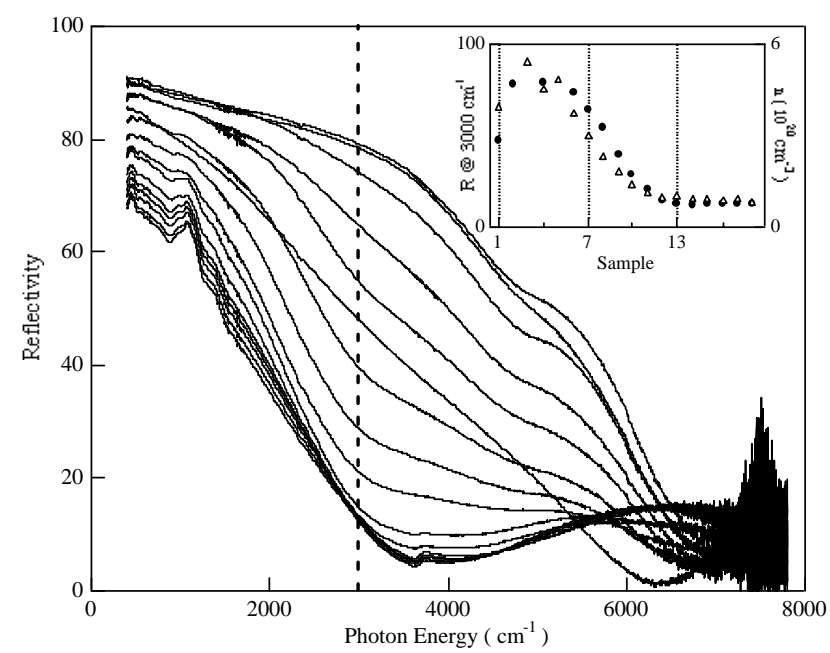

Fig. 3. FTIR reflectivity measurement of a Cd-Sn-O library.

combinatorial characterization of the relative carrier concentration in TCO libraries.

\section{Additional Libraries}

Using gray-scale intensity maps, Figure 4 summarizes several properties of a $\mathrm{Zn}(\mathrm{Al}) \mathrm{O}$ library that was used for technique verification. The upper left map, which shows the infrared reflectance, indicates a higher electron density on right side of the sample. The thickness, upper right map, shows good uniformity with thicknesses between 2000 and $3000 \AA$. The bulk conductivity map is shown in the bottom left. The bottom right graph shows the conductivity, reflectance at $2000 \mathrm{~cm}^{-1}$, and the relative aluminum content, measured using electron microprobe, vs. column position for row 3 . For this sample, the conductivity generally scales as expected with $\mathrm{Al}$ content.

We are now applying the developed combinatorial tools to the $\mathrm{Zn}-\mathrm{Sn}-\mathrm{O}$ binary TCO system. Initial results (10 libraries) suggest that $\mathrm{ZnSnO}_{3}$ may be a substantially better TCO than $\mathrm{Zn}_{2} \mathrm{SnO}_{4}$, which is presently used as an interface layer in $\mathrm{CdS} / \mathrm{CdTe}$ solar cells. If sufficiently conducting $\mathrm{Zn}-\mathrm{Sn}-\mathrm{O}$ can be developed, it may be possible to eliminate the current $\mathrm{Cd}_{2} \mathrm{SnO}_{4}$ TCO layer in these $\mathrm{CdS} / \mathrm{CdTe}$ cells. These early results from our initial $\mathrm{Zn}-\mathrm{Sn}-\mathrm{O}$ libraries demonstrate the great potential for combinatorial approaches.

\section{REFERENCES}

[1] T.J. Coutts, D.L. Young, and X.N. Li, "Characterization of transparent conducting oxides," MRS Bulletin 25, 58 (2000).

[2] D.S. Ginley and C. Bright, "Transparent conducting oxides," MRS Bulletin 25, 15 (2000).

[3] R.G. Gordon, "Criteria for Choosing Transparent Conductors," MRS Bulletin 25, 52 (2000).

[4] T.J. Coutts, D.L. Young, and X.N. Li, "Fundamental Advances in Transparent Conducting Oxides," Mat. Res.

Soc. Symp. Proc. 623, 199 (2000).

[5] J.D. Perkins et al., "A Combinatorial Approach to TCO Synthesis and Characterization," Mat. Res. Soc. Symp. Proc. 666, F1.6 (2001).
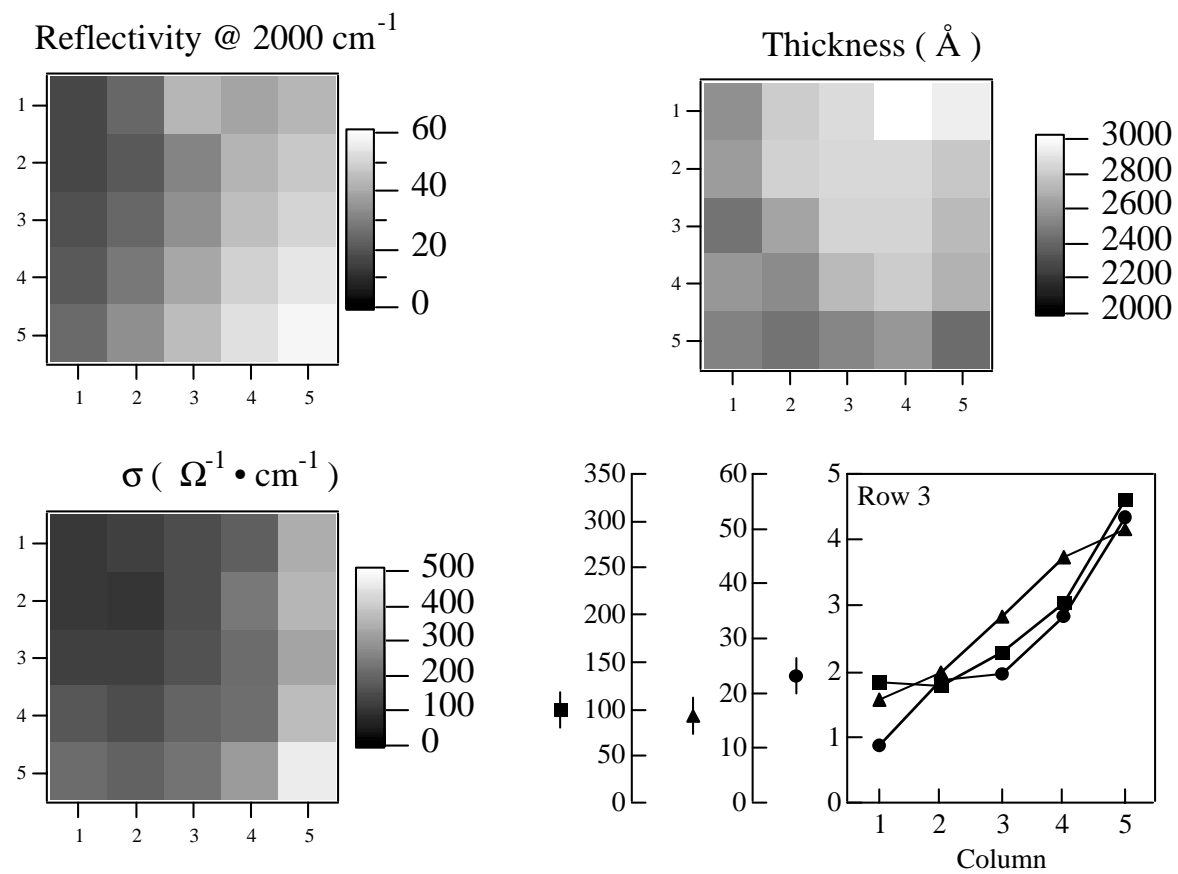

Fig. 4. Gray-scale intensity maps of relevant materials properties in a sputtered $\mathrm{Zn}(\mathrm{Al}) \mathrm{O}$ library. 